\title{
URBANISMO SUBTERRÂNEO - ARGUMENTOS PARA UM MARCO JURÍDICO DO CONTROLE DA UTILIZAÇÃO DO ESPAÇO DO SUBSOLO URBANO.
}

\section{URBAN UNDERGROUND ARGUMENTS LEGAL FRAMEWORK FOR CONTROL OF THE USE OF UNDERGROUND URBAN SPACE.}

${ }^{1}$ Sérgio Pacheco

\section{RESUMO}

O presente artigo tem como tema o Direito Urbanístico. Seu objetivo principal é a reflexão acerca do marco jurídico para utilização do espaço subterrâneo urbano, de forma a estabelecer diretrizes para o planejamento municipal que leve em consideração os limites e potencialidades do espaço público subterrâneo das cidades. $O$ procedimento metodológico utilizado foi a pesquisa documental indireta, com consulta a fontes primárias legislativas e, eventualmente, documentos judiciais, bem como a fontes secundárias, através de investigação bibliográfica. $\mathrm{Na}$ pesquisa, identificaram-se práticas internacionais e a existência de normas de gestão do espaço público subterrâneo em algumas cidades brasileiras (São Paulo, Rio de Janeiro, Belo Horizonte e Porto Alegre). A investigação possibilitou apontar potencialidades e limitações na gestão municipal que podem contribuir para indicação de um plano diretor subterrâneo, de forma a disciplinar o modo de ocupação e as condutas dos interessados na exploração desse bem jurídico, fazendo, assim, valer as normas legais com a devida utilização dos recursos jurídicos disponíveis.

Palavras-chave: Direito urbanístico, Planejamento urbano, Subterrâneo, Subsolo

\begin{abstract}
This article focuses on the urban law. Its main objective is the reflection on the legal framework for the use of urban underground space, in order to establish guidelines for municipal planning that takes into account the limits and potential of underground public space of cities. The methodological procedure used was the indirect documentary research, consultation with the legislative primary sources and eventually court documents, as well as secondary sources, through bibliographical research. In the survey, international practices were identified and the existence of management practices of the underground public space in some Brazilian cities (São Paulo, Rio de Janeiro, Belo Horizonte and Porto Alegre). The research allowed pointing potentialities and limitations in municipal management that can contribute to indication of an underground master plan in order to discipline the occupation mode and conduct of those interested in exploring this legal right, making thus enforce legal standards to proper use of available legal remedies.
\end{abstract}

Keywords: Urban law, Urban planning, Underground, Subsoil

\footnotetext{
${ }^{1}$ Doutorando em Direito pela Universidade de Lisboa - UL, Lisboa (Portugal). Professor em Direito Ambiental pelo Instituto Elpídio Donizetti - IED, Minas Gerais (Brasil). E-mail: sergiopadv@ hotmail.com
} 


\section{1 - INTRODUÇÃO}

Os motivos que despertaram interesse em pesquisar o tema marco jurídico para utilização do espaço subterrâneo urbano decorrem da percepção do autor deste artigo acerca do aumento da utilização do subsolo das cidades para instalação de uma série de novos e velhos serviços que necessitam de rede subterrânea em todo mundo e especialmente nas grandes cidades brasileiras.

O avanço tecnológico acelerado e o aumento da demanda por serviços que utilizam o espaço subterrâneo das vias públicas trazem um novo desafio para a gestão das grandes cidades, que é a efetiva regulação do direito ao subsolo urbano. À medida que surgem novas empresas para instalar seus serviços em rede subterrânea, o espaço torna-se cada vez mais limitado e a hipótese de esgotamento do uso do subsolo vai se tornando uma realidade. No longo prazo, a utilização livre e desenfreada do subsolo pode ser predatória para o ambiente urbano da cidade, comprometendo a qualidade de vida dos cidadãos.

O objetivo deste trabalho é investigar a existência de normas jurídicas para controle público do uso e ocupação do subsolo urbano, a experiência internacional e de algumas cidades brasileiras, de forma a contribuir para a reflexão sobre o planejamento e o marco jurídico para utilização do espaço subterrâneo urbano.

Sob essa ótica, constatou-se que nas cidades brasileiras a regra é o descontrole e a falta de planejamento público para ocupação do subsolo urbano, apesar da existência de normas, quase sempre desconexas, sobre o assunto. Daí, a necessidade de se identificar as formas de intervenção no subterrâneo urbano para, finalmente, expor as potencialidades da gestão do subsolo e a necessidade do planejamento para desenvolver a exploração desse espaço.

Neste contexto, o primeiro capítulo será reservado à introdução ao tema da pesquisa. Na sequência, o segundo capítulo busca caracterizar as diversas intervenções no subsolo na era urbana atual. O terceiro capítulo aborda o subsolo como bem jurídico e apresenta a tutela para sua proteção na ordem jurídica brasileira.

O quarto capítulo propõe-se à reflexão acerca do direito de superfície e da titularidade do direito à exploração do espaço subterrâneo. Para tanto, serão estudadas as abordagens relativas ao direito de superfície, constantes no Estatuto da Cidade (Lei $\mathrm{n}^{\circ}$ 10.257/2001) e no Código Civil Brasileiro (Lei n ${ }^{\circ}$ 10.406/2002), ressaltando o aparente conflito entre esses dois Institutos, no que tange ao direito de propriedade do subsolo. 
No quinto capítulo serão apresentados aspectos gerais da experiência internacional de controle do poder público do uso do subterrâneo urbano. Já no capítulo sexto seguinte destaca-se os aspectos da experiência brasileira, bem como características das legislações municipais das cidades de São Paulo, Rio de Janeiro, Belo Horizonte e Porto Alegre, referentes ao controle do uso do subsolo urbano.

O sétimo capítulo propõe a reflexão acerca das possibilidades e limitações na gestão municipal do subsolo, em especial a necessidade de elaboração dos Planos Diretores Municipais que levem em consideração o efetivo planejamento do subsolo.

Nas considerações finais serão expostos os caminhos percorridos na pesquisa, com especial ênfase às potencialidades e desafios para possibilitar a ocupação do subsolo urbano.

A hipótese que será defendida neste trabalho, e ao final será levada ao leitor, será o entendimento de que os benefícios e limitações do uso do subsolo urbano só podem ser verificados caso o poder público assuma o planejamento urbano efetivo, incorporando no marco jurídico regulatório e no planejamento da cidade a dimensão do espaço subterrâneo como premissa para o desenvolvimento urbano.

Esclarece-se, ainda, não se pretender esgotar o tema em todos os seus possíveis aspectos, sobretudo em razão das limitações impostas pelo rigor científico quanto ao recorte do objeto de pesquisa. Objetiva-se, em verdade, provocar reflexão sobre a complexidade do mundo invisível que habita os subterrâneos das cidades e abrir caminho para novos estudos jurídicos.

Por fim, informa-se que foi adotado como técnica de pesquisa a documentação indireta, com consulta a fontes primárias legislativas e, eventualmente, documentos judiciais, bem como a fontes secundárias, mediante investigação bibliográfica. O estudo foi desenvolvido por meio do emprego do método hipotético-dedutivo, partindo-se de argumentos gerais formulados no referencial teórico para, então, proceder-se ao desenvolvimento de raciocínio em direção à da hipótese firmada.

\section{O SUBSOLO NA ERA URBANA}

Este item destina-se a caracterizar brevemente alguns tipos de intervenções no subsolo urbano ao longo da história e a complexidade das intervenções atuais. 
2.1 O uso do subsolo urbano ao longo da história

A ocupação do espaço subterrâneo pelo ser humano não é um fenômeno recente. $\mathrm{Na}$ Capadócia, hoje parte da Turquia, os primeiros cristãos usavam uma elaborada rede de túneis para se proteger de exércitos romanos, conquistando verdadeiras cidades subterrâneas, que hoje em dia constituem atrações turísticas.

Conforme a tecnologia evolui, também tem aumentado os tipos de intervenções no subsolo urbano. Na década de 1860, Londres começou a instalar a rede de trens no espaço subterrâneo e criou o primeiro metrô. Cem anos mais tarde, Montreal instalou lojas no subsolo, vindo a inaugurar um shopping subterrâneo. Aplicações militares subterrâneas proliferaram na segunda metade do século XX, como a construção de abrigos de quintal nos Estados Unidos, bem como o complexo militar secreto do Comando de Defesa Aeroespacial Norte-americano, dentro da Cheyenne Mountain, no Estado de Colorado, e uma fábrica de submarino soviético no subsolo, na Ucrânia.

Hoje o impulso subterrâneo no mundo todo é motivado não tanto por segurança ou pela expansão do comércio, mas, sobretudo, pela necessidade de economizar espaço e preservar recursos naturais. Seguindo as atuais projeções de aumento da população mundial (ORGANIZAÇÃO DAS NACÕES UNIDAS - ONU, 2012), isso significa que vão subir também as demandas de infraestrutura urbana, tais como a necessidade de mais energia, mais água, mais eliminação dos resíduos e, acima de tudo, mais espaço para casas, estradas e áreas de lazer.

No caso do Brasil, os dados do censo de 2010 apontaram uma população superior a 190 milhões de pessoas, sendo que aproximadamente $84 \%$ dessa população vive em áreas urbanas (mais de 160 milhões de pessoas), um aumento superior a 3\% (três por cento) em relação à população urbana no senso de 2000 (CENSO DEMOGRÁFICO 2010, 2011).

Em todo mundo, a disponibilidade de espaço adequado para suprir as necessidades da população torna-se cada vez mais difícil em função do aumento da demanda do solo para suprir as necessidades criadas por um padrão de consumo dependente das utilidades e equipamentos urbanos como transporte, energia e telecomunicação (GLOBAL FOOTPRINT NETWORK, 2011).

Não há como imaginar que essas necessidades serão supridas no espaço da superfície das cidades. Dessa forma, o espaço subterrâneo tem aparecido como uma nova fronteira para o desenvolvimento das cidades. 
2.2 Espaços subterrâneos contemporâneos - modalidades de serviços e equipamentos de intervenções no subsolo urbano

O subsolo urbano, em especial o delimitado pelo espaço das vias e logradouros públicos tem se mostrado como uma boa alternativa para locação dos chamados serviços em redes, como é o caso dos equipamentos de redes de distribuição de energia elétrica, telecomunicações, gás, água, dentre outros. ${ }^{1}$ Entretanto, à medida que surgem novas tecnologias e novas empresas dispostas a instalar seus serviços, o subsolo torna-se cada vez mais limitado e a hipótese de esgotamento do espaço subterrâneo nas cidades vai se tornando uma realidade.

Utilizado inicialmente para a instalação de dutos de redes de água e esgotos, e pequenos túneis que possibilitassem a fuga ou acesso rápido, o subsolo urbano, espaço antes inexplorado e invisível à maior parte da população, é ocupado atualmente por redes de energia elétrica e de telecomunicação; rede de distribuição de gás; coleta de lixo e esgoto; drenagem pluvial, estacionamentos de veículos automotores e bicicletas; sistemas de transporte de alta capacidade (metro); e parte de estrutura de edifícios comerciais e residenciais, dentre outros.

No Brasil, semelhante ao que acontece em outras cidades no mundo todo, é notável a expansão da utilização do subsolo para atender as atuais demandas urbanas. No entanto, o marco jurídico atual, bem como a gestão do espaço subterrâneo, não tem acompanhado essa dinâmica.

\section{O SUbSOlO COMO BEM JURÍdico E A TUTELA PARA PROTEÇÃo NA ORDEM JURÍDICA BRASILEIRA}

Sem perder a perspectiva do enfoque no subsolo urbano, embora vá além do escopo deste trabalho, faz-se necessário constar a existência na legislação brasileira de normas específicas de proteção do subsolo para efeitos dos recursos minerais (em especial o DecretoLei no 227/1967, que estabelece o Código de Mineração) e da proteção de cavidades naturais subterrâneas e sítios arqueológicos (como por exemplo o Decreto $n^{\circ}$ 99.556/1990,

\footnotetext{
${ }^{1}$ Para Eloisa Carvalho de Araújo, pesquisadora integrante do LADU - Laboratório de Direito e Urbanismo do PROURB-FAU-UFRJ: "Não é de hoje que as redes de infraestrutura cumprem papel fundamental na estruturação do espaço urbano. Mas é, sobretudo, na contemporaneidade que elas passam a desempenhar um novo papel social, sendo determinantes na geração de oportunidades para a população, proporcionando espaços privilegiados nas cidades. O uso do espaço do subsolo tem um papel importantíssimo no contexto da 'produção de espaço urbano' enquanto instrumento de transformação de solo urbano em solo urbanizado e de solo urbanizado em solo construído". (ARAÚJO, 2011)
} 
posteriormente alterado pelo Decreto $\mathrm{n}^{\mathrm{o}}$ 6.640, de 07 de novembro de 2008, que regulamenta a proteção das cavidades naturais subterrâneas existentes no território nacional).

No Brasil, sob a égide da Constituição da República de 1988, o solo e o subsolo passaram a obedecer a relações jurídicas que vão além dos interesses individuais, impondo limitações ao uso privado desses espaços em favor das necessidades e usos comuns pela população, passando a ter natureza jurídica de bens ambientais, conforme o art. $3^{\circ}$, inciso $\mathrm{V}$, da Lei ${ }^{\circ}$ 6.938/1981, Política Nacional do Meio Ambiente.

Nos termos da legislação brasileira, o Município torna-se proprietário do solo urbano, quer em decorrência de desapropriação (art. 5\%, alínea “i”, do Decreto-Lei no $3.365 / 1941$, que dispõe sobre desapropriações por utilidade pública), quer em consequência de registro do loteamento (art. 22 da Lei $n^{\circ}$ 6.766/1979, que dispõe sobre o parcelamento do solo urbano), quer, ainda, em virtude de doação de particulares. Pode, ainda, o Município incorporar ao seu patrimônio bens imóveis na hipótese de herança vacante, nos termos do art. 1.844 da Lei no 10.406/2002, o "Novo Código Civil”, de 2002.

No que tange ao direito de uso do subsolo urbano, a matéria encontra-se definida em normas infraconstitucionais, especialmente no Estatuto da Cidade (Lei $\mathrm{n}^{\circ} 10.257 / 2001$ ) e no Código Civil (Lei 10.406/2002). Entretanto, a doutrina aponta divergência em vários aspectos entre esses Institutos, como, por exemplo, em relação ao direito de superfície, o que será estudado a seguir.

\section{O DIREITO DE SUPERFÍCIE: A QUEM PERTENCE O ESPAÇO SUBTERRÂNEO URBANO?}

Serão abordados, na sequência, alguns aspectos relativos às posições doutrinárias acerca do direito de uso do espaço subterrâneo dos terrenos urbanos.

\subsection{O Estatuto da Cidade (Lei n $\left.{ }^{\circ} 10.257 / 2001\right)$}

O Estatuto da Cidade, legislação inspirada nas necessidades da sociedade brasileira moderna, nasce dos anseios de se organizar os centros urbanos no País. Diploma promulgado em razão dos ditames dos artigos 182 e 183 da Constituição da República, tem como objetivo a regulamentação da política urbana. 
O Estatuto da Cidade regulamentou, pela primeira vez no ordenamento jurídico nacional, o direito de superfície. Conforme definido no seu art. 21, ficou instituído o direito de superfície do proprietário, estendendo esse direito à utilização do subsolo. ${ }^{2}$

Em decorrência dessa Lei, o proprietário tem o direito ao subsolo relativo ao seu terreno, atendido a "legislação urbanística". Essa subordinação aos interesses da Administração, ou seja, a legislação urbanística, fundamenta-se no Princípio da Função Social da Propriedade, descrito no art. 5, XXIII, da CR de 1988. Nesse contexto, a utilização do subsolo por particular estaria subordinada à disciplina e à outorga de direito de uso do poder público, de forma a garantir os objetivos maiores das políticas urbanas, ou seja, organizar a ocupação, edificar, fazer construções na área objeto do direito em comento em função do interesse público.

\subsection{Código Civil Brasileiro (Lei n ${ }^{\circ}$ 10.406/2002)}

No caso do Código Civil, a perspectiva de regulação dos direitos é mais ampla do que o definido no Estatuto da Cidade, abrangendo também as propriedades localizadas em áreas rurais.

O art. 79 do Código Civil define que "são bens imóveis o solo e tudo quanto se lhe incorporar natural ou artificialmente". Mais precisamente, o art. 1.369 do Código Civil dissocia o direito de uso da superfície do direito de uso do subsolo. ${ }^{3}$ Decorre da leitura do art. 1.369 que apenas o uso do solo estaria abarcado pela concessão de direito de superfície, devendo o uso do subsolo e do espaço aéreo estar previsto ou no instrumento de concessão ou ser uma decorrência da natureza desta concessão.

No que tange ao subsolo, o art. 1.229 do Código Civil disciplina o regime jurídico não tutelado pela legislação minerária brasileira. ${ }^{4}$

\footnotetext{
${ }^{2}$ Artigo 21. O proprietário urbano poderá conceder a outrem o direito de superfície do seu terreno, por tempo determinado ou indeterminado, mediante escritura pública registrada no cartório de registro de imóveis.

$\S 1^{\circ} \mathrm{O}$ direito de superfície abrange o direito de utilizar o solo, o subsolo ou o espaço aéreo relativo ao terreno, na forma estabelecida no contrato respectivo, atendida a legislação urbanística. (grifamos)

${ }^{3}$ Art. 1.369. O proprietário pode conceder a outrem o direito de construir ou de plantar em seu terreno, por tempo determinado, mediante escritura pública devidamente registrada no Cartório de Registro de Imóveis.

Parágrafo único. O direito de superfície não autoriza obra no subsolo, salvo se for inerente ao objeto da concessão.

${ }^{4}$ Para definir o alcance e o conteúdo daquela propriedade, dispõe o art. 1.229: “A propriedade do solo abrange a do espaço aéreo e subsolo correspondentes, em altura e profundidade úteis ao seu exercício, não podendo o proprietário opor-se a atividades que sejam realizadas por terceiros, a uma altura ou profundidade tais, que não tenha ele interesse legítimo em impedi-las".
} 
Neste ponto, para melhor compreensão, cabe realçar a divergência de abordagem existente no Estatuto da Cidade e no Código Civil de 2002 acerca da possibilidade de fracionamento da superfície. Para o Estatuto, o direito de superfície abrange o direito de utilizar o solo, o subsolo e o espaço aéreo relativo ao terreno, até certo limite, devendo, entretanto, obedecer às legislações urbanísticas. Já o Código Civil não autorizou a realização de obra no subsolo, salvo se inerente ao objeto da concessão. Nada disse, porém, sobre o espaço aéreo.

Um exemplo prático: caso se adote o que diz o Código Civil - que não permite obra no subsolo, salvo se for inerente ao objeto da concessão (parágrafo único do art. 1.369 do CC), não seria possível a transferência do direito de superfície para construção exclusivamente de uma garagem subterrânea em terreno de terceiro. No entanto, seria possível a construção dessa mesma garagem, desde que sobre ela fossem edificados diversos andares, como uma superfície tendo como objeto a construção de um centro comercial.

Ainda seguindo o raciocínio do mesmo exemplo, no caso de se utilizar a interpretação do Estatuto da Cidade, o proprietário do terreno poderia transferir a outro o direito de construir somente a garagem subterrânea, já que a limitação não incide, pois o direito de superfície abrange o direito de utilizar o subsolo (parágrafo primeiro do artigo 21 do EC), desde que esteja de acordo com as normas administrativas municipais.

Ante a colisão em abstrato dos dispositivos legais, no ponto de vista doutrinário a aparente divergência encontra opiniões distintas. Para alguns doutrinadores o Código Civil encontra-se posto como norma geral e o Estatuto da Cidade como microssistema, sob enfoque de norma especial.

Parte da doutrina considera que, nos termos do parágrafo $1^{\circ}$ da Lei de Introdução ao Código Civil, neste ponto o Código Civil que entrou em vigor em 2004 teria revogado o Estatuto da Cidade, que é de 2001, haja vista que teria regulado a mesma matéria, ou seja, o direito de superfície. Nessa linha é o entendimento de J. Miguel Lobato Gómes (2004), para quem o Novo Código Civil incorporou os princípios da Constituição da República de 1988, sendo uma lei nova que revoga as anteriores, naquilo que não houver compatibilidade.

Para Caramuru Afonso Francisco (2001) prevalece a natureza de lei complementar do Estatuto da Cidade, que foi editado para regulamentar os artigos 182 e 183 da Constituição da República de 1988, pelo que incidiria, pela espécie, o princípio expresso no brocardo "lex superior derogat legi inferior".

Todavia, melhor defesa será conduzida por Sílvio de Salvo Venosa (2002) que, por ocasião da I Jornada de Direito Civil, realizada pelo Conselho da Justiça Federal - CJF e pelo 
Centro de Estudos Jurídicos do CJF, com participação de especialistas e convidados do mais notório saber jurídico, elaborou os Enunciados $n^{\circ} 93$ e 94, reafirmando a validade do Estatuto da Cidade no que tange à disciplina do direito de superfície. ${ }^{5}$

Em casos como este de divergências de legislações, Maria Helena Diniz (2001, p.78) recomenda utilizar a prudência. Destarte, no presente caso, de eventual conflito entre Estatuto da Cidade e o Código Civil, o correto é procurar integrar os dois textos que, na verdade, têm a mesma filosofia e estrutura, sendo possível superar supostas contradições. Um exame mais acurado revelará que, de fato, não há incompatibilidade insuperável entre os dois regramentos, mas antinomias aparentes.

Não há qualquer dúvida que o legislador quis em algum momento revogar o Estatuto da Cidade. O ideal é se proceder à interpretação sistemática, única, conjunta e integrada, de todo o complexo normativo relativo ao tema, a partir do caso concreto. "O Estatuto da Cidade deve ser utilizado quando o direito de superfície incidir em imóveis citadinos e for instrumento de política urbana" (RESENDE, 2010, p. 64).

Toshio Mukai, em sua obra Temas atuais de Direito Urbanístico e Ambiental, destaca ainda que tem sido discutido, inclusive na via judicial, a legalidade e a constitucionalidade ou não, do fato de alguns Municípios pretenderem cobrar pela utilização do subsolo, por empresas privadas, para a passagem de cabos de comunicação e de fibras óticas, pretende-se cobrar também (não se sabe de quem) pela colocação de postes nas vias públicas (nas calçadas).

\footnotetext{
Temos visto as mais absurdas afirmações e decisões em liminares, dando pelo eventual inconstitucionalidade da "taxa" de cobrança; tratar-se-ia de propriedade da União (o subsolo); falta de competência do Município para efetuar tal cobrança; competência da União, por lei federal, para efetivação da referida cobrança de taxa, etc.

Entendemos que a pretensão do Município de cobrar um preço público, por decreto (não se trata do tributo, taxa), é legal, constitucional e absolutamente procedente.

Os bens públicos, comuns do povo e de uso especial, são de domínio do Município, como se sabe (a Lei $n^{\circ} 6.766 / 79$, no seu artigo 22 diz que as ruas, praças, áreas livres e os equipamentos comunitários passam ao domínio do Município, pelo registro do loteamento).

Ora, se alguém pretende utilizar-se do subsolo, acima do solo que pertence ao Município, nada mais curial que obtenha a concessão de uso ou a permissão de uso, desse Município, pois o subsolo também pertence a este (o artigo 1.229 do Código Civil dispõe que: "A propriedade do solo abrange a do espaço aéreo e subsolo
}

\footnotetext{
${ }^{5}$ Enunciado 93 - Art. 1.369: As normas previstas no Código Civil sobre direito de superfície não revogam as relativas a direito de superfície constantes do Estatuto da Cidade (Lei n. 10.257/2001) por ser instrumento de política de desenvolvimento urbano.

Enunciado 94 - Art. 1.371: As partes têm plena liberdade para deliberar, no contrato respectivo, sobre o rateio dos encargos e tributos que incidirão sobre a área objeto da concessão do direito de superfície. (JUSTIÇA FEDERAL, 2012, p. 25-26)
} 
correspondentes, em altura e profundidade úteis ao seu exercício, não podendo o proprietário opor-se a atividades que sejam realizadas por terceiros, a uma altura ou profundidade tais que, não tenha interesse legítimo em impedi-las").

Portanto, se o subsolo pertence ao Município, para que alguém possa usufruir; terá que obter concessão ou permissão daquele, para esse uso, devendo pagar um preço público, para tal. Advirta-se que a assertiva de que o subsolo pertenceria à União, "data vênia" dos que assim dizem, é equivocada. O que a Constituição afirma ser de propriedade da União, não é o subsolo como um todo, mas apenas as jazidas, em lavras ou não, e demais recursos minerais e os potenciais de energia hidráulica constituem propriedade distinta da do solo, para efeito de exploração ou aproveitamento, e pertencem à União (artigo 176 da CF). (MUKAI, 2007)

4.3 Direito de propriedade do subsolo e a jurisprudência do Superior Tribunal de Justiça

Quanto ao direito de propriedade do subsolo urbano, em decisão da Terceira Turma do Superior Tribunal de Justiça (STJ), Recurso Especial $\mathrm{n}^{\circ}$ 1233852, publicada em 01/02/2012, a relatora ministra Nancy Andrighi analisou se o direito de construir previsto no art. 1.299 do Código Civil abrange inclusive o subsolo.

A ação original teve caráter indenizatório por danos materiais e morais, decorrentes de obras executadas por dono de imóvel vizinho, principalmente escavações, realizadas em uma propriedade.

Em primeira instância, o juiz determinou que os vizinhos pagassem indenização por danos materiais e também que retirassem os tirantes utilizados na ancoragem da parede de contenção erguida. Na apelação, o Tribunal de Justiça do Rio Grande do Sul manteve a indenização, mas afastou a determinação de remoção dos tirantes.

No recurso especial, os proprietários alegaram violação aos artigos 1.229 e 1.299 do Código Civil, que tratam, respectivamente, da propriedade do subsolo e do direito de construir. Eles argumentaram que o subsolo seria parte integrante da superfície da área e sua exploração não autorizada constituiria esbulho.

De acordo com a Ministra Nancy Andrighi, não houve nenhum prejuízo ou restrição ao direito de uso, gozo e fruição da propriedade e, ainda, que a parcela do subsolo utilizada para a realização de obras (a quatro metros do nível do subsolo) não devia ser considerada parte integrante da outra propriedade. A turma negou provimento ao recurso especial. Logo, o direito de propriedade do solo abrange o subsolo, porém o seu alcance é limitado a uma profundidade útil ao seu aproveitamento, o que impede o proprietário de se opor a atividades realizadas por terceiros em espaço sobre o qual ele não tenha interesse legítimo. Com esse entendimento, a Terceira Turma do Superior Tribunal de Justiça (STJ) negou provimento ao recurso especial. (BRASIL, 2011) 
Assim, pode-se questionar se esse entendimento poderá ser ainda plausível diante de complexas relações entre a autonomia pública e a autonomia privada e o papel das cidades nos desafios do presente século.

\title{
5 A EXPERIÊNCIA INTERNACIONAL DE INTERVENÇÃO NO SUBSOLO URBANO
}

O atual e caloroso debate envolvendo do direito subterrâneo já se fazia presente no âmbito da reunião anual da Internacional Tunnelling Association - ITA, realizada em 1991, na cidade de Londres, na Inglaterra. Naquela ocasião, a Assembleia Geral pronunciou uma "Declaração Política sobre problemas judiciais e administrativos no uso do espaço subterrâneo":

\begin{abstract}
(...) A consciência da opção subterrânea entre os planejadores, desenvolvedores e financistas deve ser aumentada, de modo a que as questões de planejamento do subsolo sejam devidamente tratadas. O planejamento do subsolo deve ser uma parte integrante do processo de planejamento normal de uso da terra.

Políticas nacionais, regionais e locais devem estar preparadas para fornecer diretrizes, critérios e classificações para avaliar o uso apropriado do espaço subterrâneo, identificar as condições geológicas, definindo usos prioritários e resolução de potenciais conflitos de utilização. Políticas de reserva de locais devem ser estabelecidas para uso importante no futuro e para, especialmente, estabelecer condições geológicas favoráveis.

É recomendável que todas as regiões ou cidades estabeleçam um sistema de registro permanente e detalhado do uso do subsolo.
\end{abstract}

Nikolai Bobylev, do Centro de Pesquisa e Cooperação Interdisciplinar em Meio Ambiente, da Academia de Ciências da Rússia, ao analisar a incorporação do planejamento do uso e ocupação do subsolo urbano nos planos diretores municipais em várias cidades mundiais, considera que:

Na maioria das cidades, o planejamento do uso do espaço subterrâneo não foi incorporada nos Planos Diretores. Em vez disso, o planejamento foi encomendado em função da demanda de determinados setores, como empresas de abastecimento de água, telecomunicações e energia elétrica. Assim, a viabilidade de cada empreendimento simplesmente foi considerada em relação com a sua interação com a infraestrutura existente.

O problema do uso do espaço subterrâneo desorganizado é mais grave em países cuja legislação prevê fortes direitos de propriedade privada da terra, por exemplo, Japão. A cidade de Tóquio tem restrições específicas para o desenvolvimento de projetos subterrâneos, relacionadas com questões jurídicas da propriedade privada da terra, incluindo o espaço subterrâneo debaixo desta terra. Por esta razão, importantes infraestruturas públicas subterrâneas pertencem às autoridades, incluindo estradas e prédios públicos, o que possibilita a presença de redes de metrô mais longas e de densidades mais elevadas. (BOBYLEV, 2009, p. 1132-1133) 
Para Nikolai Bobylev, a legislação fundiária é apenas um aspecto de governança do uso do espaço subterrâneo, que inclui todo o conjunto de salvaguardas ambientais, políticas de extração de recursos minerais e segurança pública (por exemplo, a interferência com as águas subterrâneas).

\subsection{São Petersburgo - Rússia}

A pesquisa de Nikolai Bobylev (2009) revela que a cidade russa de São Petersburgo, fundada em 1703, desde 1948 possui Planos Diretores para nortear o desenvolvimento urbano. O Plano Diretor publicado em 1996 já fazia considerações sobre o uso do espaço subterrâneo urbano.

Mas é no atual "Plano Diretor de São Petersburgo e Fronteiras da Zona Cultural de Proteção do Patrimônio", aprovado pelo parlamento da cidade em 2005, que inclui planejamento de curto prazo (até 2015) e longo prazo (até 2025), que se apresenta, pela primeira vez, a preocupação real pelo subsolo.

O apêndice do atual Plano Diretor de São Petersburgo inclui um capítulo especialmente voltado para as questões do subsolo urbano, intitulado "Integrated underground space development conception for St. Petersburg City Master Plan”. Verificou-se que as preocupações com o desenvolvimento futuro do espaço subterrâneo urbano são abordadas no documento de forma apenas conceitual. O Plano apresenta sugestões para estabelecer reserva de terrenos visando a implantação de projetos futuros para ligar sistemas de transporte, bem como se propõe reserva de subsolos públicos multifuncionais no centro da cidade. No entanto, todas as sugestões encontram-se no nível conceitual e não incluem estudos de viabilidade, o que, na opinião de Nikolai Bobylev é uma falha no Plano Diretor de São Petersburgo, especialmente pela falta de análise da sustentabilidade ambiental e de estudos de integração entre infraestrutura, o consumo de energia e a qualidade do ar.

\subsection{Tóquio e Kobe - Japão}

A ocupação do subsolo em algumas cidades japonesas caracterizam-se pelo planejamento do uso extensivo de subterrâneo profundo para aumentar a resistência aos perigos naturais urbanos. 
No Japão, com o objetivo de permitir a utilização de espaços subterrâneos profundos para instalação de infraestrutura pública, foi aprovada em maio/2000, entrando em vigor em 01/04/2001, a Lei de Medidas Especiais para Uso Público do Subsolo ${ }^{6}$. A ideia é que o uso público do espaço que está distante e suficientemente abaixo da superfície não venha a colidir com os direitos dos proprietários das áreas da superfície e, portanto, não sendo devida nenhuma compensação a esses proprietários.

Prevê-se que os equipamentos de infraestrutura considerados críticos e indispensáveis à população, tais como linhas de energia elétrica, cabos de comunicação, água e tubos de saneamento e linhas de gás podem ser ligados em rede dentro de um sistema de canal único e grande que é enterrado no mais profundo no subsolo, até mais de 40 metros abaixo da superfície. Isto irá contribuir tanto para a prevenção de desastres como para a renovação ambiental urbana na superfície.

Iniciada há mais de 50 anos atrás, principalmente como uma maneira de reduzir o uso invasivo do subsolo e o congestionamento de tráfego subterrâneo, acredita-se que os benefícios ambientais e de segurança da utilização dos condutos subterrâneos tem-se tornado cada vez mais evidente ao longo do tempo.

Atualmente, a maioria dos condutos subterrâneos nas cidades japonesas foi construída em profundidades mais rasas, sendo os equipamentos e imobiliários de propriedade pública, como principais estradas arteriais.

Contudo, o governo municipal de Kobe, por exemplo, já vem aplicando a Lei de Medidas Especiais para Uso Público do Subsolo na realização de 250 metros de obras de construção de um gasoduto, de modo a permitir o uso subterrâneo profundo a uma profundidade superior a 40 (quarenta) metros abaixo de terras privadas, possibilitando encurtar o comprimento da rota e reduzir o custo do projeto.

Na cidade de Tóquio, existem mais de 110 quilômetros de condutos subterrâneos sob o sistema de rodovias metropolitanas. Entretanto, há planos para fazer pleno uso da Lei de 2001, para incrementar a instalação do transporte público por meio de trens subterrâneos de alta velocidade e estradas subterrâneas, além de outros equipamentos indispensáveis à população.

Além disso, o Ministério da Infraestrutura e dos Transportes do Japão decidiu aplicar a Lei de Medidas Especiais para Uso Público do Subsolo a fim de promover a construção de

\footnotetext{
${ }^{6}$ Maiores informações sobre a experiência japonesa no planejamento do espaço subterrâneo nas cidades, consultar o endereço eletrônico da Desurbs - Designing Safer Urban Spaces. Disponível em: <http://www.desurbs.net/Japan\%20deep\%20underground.html>. Acesso em: 14 mai. 2014.
} 
uma seção do "Projeto Estrada de Tóquio Outer Ring", entre Nerima e Setagaya (extensão aproximada de $16 \mathrm{~km}$ ). Espera-se com isso evitar a compra de terras e a redução dos custos.

\subsection{Xangai e Pequim - China}

A cidade de Xangai, na China, fornece um exemplo de como uma cidade pode ter problemas se não existem regulamentos de planejamento. A utilização do espaço subterrâneo em Xangai, como em muitas outras cidades chinesas, vem crescendo rapidamente nas últimas duas décadas, mas os conflitos com usos anteriores podem causar grandes dificuldades. Por exemplo, os planejadores da cidade foram obrigados a desviar alinhamentos de linhas de metrô que estava sendo planejado por causa da presença de fundações de um edifício recentemente construído, aprofundando o nível planejado da passagem das linhas do metrô por mais de dezesseis metros (ITACUS, 2010, p. 4).

Em Xangai e em Pequim, regulamentos locais já foram colocados em prática para coordenar a utilização do espaço subterrâneo e evitar conflitos espaciais, regulando nomeadamente sobre os usos de estacionamento e a profundidade do espaço subterrâneo que pode ser utilizado pelos edifícios.

A capital chinesa, Pequim intensificou seus esforços para explorar o espaço subterrâneo para aliviar o congestionamento do solo, a tensão do uso da terra na área central da cidade e os problemas ambientais.

Segundo informações da imprensa de Pequim, o Beijing Instituto Municipal de Planejamento Urbano e Design fixou 17 áreas como as zonas-chave para incrementar o espaço subterrâneo da cidade. No longo prazo, uma "cidade subterrânea" que abrange 90 milhões de metros quadrados será construída até 2020, com o espaço per capita no subsolo atingindo cinco metros quadrados na cidade, de acordo com um plano do instituto (XINHUA NEWS AGENCY, 2006).

\subsection{Arnhem - Holanda}

Na Holanda, uma abordagem de planejamento integrado e a identificação do subsolo como um componente importante de planeamento tem encorajado a inclusão do espaço subterrâneo no planejamento da cidade.

Antônia Cornaro e Han Admiraal (2012) avaliam que na cidade de Arnhem, o uso do subsolo tem sido apoiado e promovido pelo Conselho da Cidade, devido à escassez total de 
espaço para o desenvolvimento e, ao mesmo tempo, a necessidade de manter e ampliar a característica espacial da cidade. Todas as partes envolvidas no processo de planejamento da cidade, em Arnhem, tanto públicas e privadas, agora precisam considerar especificamente o uso do espaço subterrâneo no seu planeamento.

\subsection{Helsink - Finlândia}

A cidade de Helsinki é considerada por planejadores e urbanistas como um exemplo internacional no tratamento do planejamento da ocupação do subsolo urbano. Foi a primeira cidade do mundo a adotar um planejamento do espaço subterrâneo como parte de sua política de desenvolvimento urbano.

Conforme acentua Antônia Cornaro (2012), o avanço da ocupação do subsolo urbano em Helsinki é facilitado pelo fato de que $60 \%$ das terras na cidade são de propriedade do governo local e de que a cidade é construída em granito sólido que é altamente favorável para escavações subterrâneas de baixo custo.

O "Underground Master Plan of Helsinki", ou Plano Diretor Subterrâneo de Helsinki, fornece a estrutura para o gerenciamento e controle de obras no subsolo da cidade e permite a indicação dos locais adequados para a serem alocados para instalações subterrâneas, sejam de serviços públicos ou explorados por particulares (VAHAAHO, 2012).

Desde 1960, mais de 400 instalações e mais de 200 quilômetros de túneis já foram construídos no subsolo. Além disso, existe o registro de mais de 200 novas reservas para projetos subterrâneos para o futuro.

Como a estrutura da cidade torna-se mais densa, mais e mais instalações adaptadas para finalidades diferentes estão sendo construídas no subsolo. Há também uma necessidade crescente para se conectar locais subterrâneos diferentes, para formar uma rede complexa e inter-relacionada. Ao planejar e executar novos projetos de construção é importante certificarse que as reservas de espaços públicos para projetos de longo prazo, tais como túneis e dutos para o tráfego e manutenção técnica estão sendo mantidos para futura construção. O crescimento da construção subterrânea e a necessidade de planejar e coordenar diferentes projetos levou à necessidade de elaboração de um Plano Diretor Subterrâneo para Helsinki.

Com status legal, o Plano Diretor também reforça a natureza sistemática e qualidade de construção subterrânea e a troca de informações relacionadas a ele.

O Plano Diretor Subterrâneo de Helsinki tem característica de um plano estratégico de preservação ambiental. Desde que adquiriu o status jurídico autônomo, os proprietários de 
terras e as autoridades têm sido obrigados a segui-lo. Ele aponta os locais reservados no subsolo para projetos-chave que são considerados importantes para a sociedade em geral, desempenhando papel vital no desenvolvimento urbano de Helsinki.

\section{A EXPERIÊNCIA BRASILEIRA DE CONTROLE DE USO E OCUPAÇÃO DO SUBSOLO URBANO}

Neste tópico serão abordados alguns aspectos da experiência brasileira na gestão do subsolo urbano, bem como a legislação de algumas capitais para disciplinar o uso do espaço subterrâneo. Tanto quanto se sabe, não houve nenhuma pesquisa abrangente e consolidada ou análise realizada em relação à legislação brasileira acerca do uso do subterrâneo urbano em cidades brasileiras.

As experiências legislativas e de controle administrativo do subsolo urbano apresentadas neste trabalho são aquelas referentes às cidades de São Paulo, Rio de Janeiro, Belo Horizonte e Porto Alegre, onde a presença de serviços e instalações subterrâneas são mais frequentes, o que não exclui a possibilidade de existirem leis e regulamentos municipais em várias outras cidades brasileiras.

\subsection{São Paulo}

Região Metropolitana de São Paulo (RMSP) é o maior aglomerado urbano do Brasil e um dos maiores do mundo. No subsolo da cidade de São Paulo estão instaladas grandes extensões de redes de infraestrutura urbana, como as redes de distribuição de energia elétrica, água e esgoto, telecomunicações, gás natural, dentre outros equipamentos.

Destaca-se o Metrô de São Paulo, primeiro do país, que começou a ser construído em 1969. A rede metroviária da cidade de São Paulo apresenta hoje extensão de $65,3 \mathrm{~km}, 58$ estações. Em suas cinco linhas, o Metrô transporta cerca de 3,5 milhões de pessoas por dia um recorde mundial em termos de demanda por quilômetro de sistema, o que reforça a necessidade de um consistente programa de investimentos neste especial sistema de transporte (ABMS, 2011).

Outro destaque refere-se às redes de distribuição de energia elétrica subterrâneas instaladas no subsolo de São Paulo; data de 1902 a construção das três primeiras câmaras transformadoras, inaugurando a implantação de redes subterrâneas. 
Conforme avaliam Silva e Machado (2001), apesar da complexidade dos serviços em rede instalados no Município, a preocupação com a gestão do subsolo é recente e os mecanismos existentes mostram-se insuficientes. Para os autores, nem o Município nem o Estado souberam ou pretenderam utilizar as redes de serviços públicos, já existentes ou em suas expansões, como mais um instrumento de inserção da parcela da população de baixo poder aquisitivo na dinâmica social e econômica da cidade.

A partir da década de 1970, observa-se a preocupação com a regulamentação do espaço subterrâneo na cidade de São Paulo, em particular para as obras e serviços executados nas vias e logradouros públicos. Algumas leis e decretos foram promulgados, como mostra o histórico apresentado por Silva e Machado (2001), sem, contudo, ter havido uma articulação direta com os organismos diretamente ligados à aprovação das obras e, principalmente, ao controle das mesmas.

O Plano Diretor Estratégico do Município foi aprovado pela Lei $\mathrm{n}^{\circ} 13.430$, de 13 de setembro de 2002.

Entretanto, conforme Raquel Rolnik:

\begin{abstract}
Novamente, o PDE avança propondo na articulação das políticas de habitação, desenvolvimento urbano, mobilidade, ambiental, entre outras. Na prática, cada pasta seguiu com suas prioridades e essa articulação não aconteceu, dispersando no território as iniciativas, inclusive com a contraposição de algumas delas, como na construção dos parques lineares, onde moradores de favelas foram despejados sem nenhuma articulação com políticas de habitação. O tratamento diferenciado aos projetos autogestionários não foi implementado. (ROLNIK, 2013)
\end{abstract}

A Lei Municipal $\mathrm{n}^{\circ} 13.614$ de 02 de julho de 2003, regulamentada pelo Decreto $\mathrm{n}^{\circ}$ 44.755, de 18 de maio de 2004, estabeleceu a obrigatoriedade de que todos os projetos, para utilização das vias públicas municipais, inclusive dos respectivos subsolos e espaço aéreo e das obras de arte de domínio municipal, para a implantação e instalação de equipamentos de infraestrutura urbana destinados à prestação de serviços públicos e privados, devem ser submetidos à análise e aprovação do Departamento de Controle de Uso de Vias Públicas CONVIAS (PREFEITURA DE SÃO PAULO, 2014).

A referida Lei tem possibilitado a utilização de subsolo municipal para abertura de túnel interligando os prédios situados ao longo das vias públicas mediante permissão de uso a título oneroso. Kiyoshi Harada (2010), ao analisar a validade da Lei $n^{\circ} 13.614 / 2003$ no que tange ao poder municipal para emissão de permissão de uso a título oneroso, esclarece que a referida lei "tem, também, amparo no art. $2^{\circ}$ da Lei no 10.257/2001 - Estatuto da Cidade - que regulamenta em âmbito nacional o disposto no art. 182 da Constituição Federal”. 
Em 2005, a Câmara Municipal de São Paulo aprovou a Lei n ${ }^{\circ} 14.023$, que obriga concessionárias, empresas estatais e operadoras de serviço a enterrar todo o cabeamento (de rede elétrica, telefonia, televisão e afins) instalado no município. A regulamentação da lei, em vigor desde 2006, prevê o enterramento de 250 quilômetros de fios e cabos por ano. Conforme afirma Raquel Rolnik (2013), se estivesse sendo cumprida a legislação, a cidade de São Paulo já teria mais de mil quilômetros de fiação subterrânea.

Em 2009 foi desenvolvido o sistema GeoCONVIAS, um sistema de informações georreferencias (mapa e banco de dados) para gerenciamento das informações de projetos previstos, em análise e aprovados, das obras em andamento e cadastro de redes. Conforme informações da Prefeitura de São Paulo:

\begin{abstract}
O sistema possui hoje aproximadamente $95 \%$ do cadastro das redes subterrâneas de permissionária e estimadamente $30 \%$ do cadastro de drenagem. Logo serão atingidas as metas de $100 \%$ das informações de projetos previstos, em análise e aprovados e obras em andamento, bem como estão em andamento as ações necessárias para complementação do cadastro de permissionárias. (CONVIAS, 2013)
\end{abstract}

A Prefeitura de São Paulo publicou no Diário Oficial do dia 14 de março de 2013, a relação definitiva de programações para implantação das Redes Subterrâneas de Equipamentos de Infraestrutura.

\title{
6.2 Rio de Janeiro
}

A cidade do Rio de Janeiro completou seus 448 anos de existência no dia $1^{\circ}$ de março de 2013. No período de 1763 a 1960 foi sede do governo federal, sendo que o status de capital do País proporcionou privilégios ao longo dos anos que se refletiram em muitas áreas, inclusive na infraestrutura. O Rio foi a terceira cidade brasileira a substituir toda a iluminação das ruas por luz elétrica.

Ao analisar a história da implantação das redes de distribuição de energia elétrica na cidade do Rio de Janeiro, destaca Juliana Martins:

Entre 1905 e 1909, a Rio Light - uma das primeiras companhias de eletricidade a chegar ao País - foi obrigada pela prefeitura a colocar condutores subterrâneos para condução de energia elétrica. Era a remodelação da capital da República, sob comando de Pereira Passos. Nas zonas urbanas de maior densidade, as canalizações eram subterrâneas. Fora da área metropolitana, a rede aérea foi a mais implantada. Em 1926, havia 19 câmaras transformadoras que passaram a ser alimentadas sob 3,8 $\mathrm{kV}$.

No livro Estudos sobre a Rio Light, coordenado por Eulália Maria Lahme Lobo e Maria Bárbara Ley, afirma-se que: 'No que se refere à tecnologia, a Rio Light foi 


\begin{abstract}
pioneira no Brasil na implantação de redes subterrâneas. Nestes sistemas, foram utilizados cabos isolados com papel impregnado a óleo, utilizado em todo o mundo, de inegáveis qualidades técnicas e alto grau de sofisticação tecnológica. A constituição de redes subterrâneas permitiu ainda o desenvolvimento da química e da tecnologia de materiais pela criação de novos produtos como cabos isolantes secos denominados etileno-proprileno e polietileno-reticulado, que substituíram o antigo cabo impregnado a óleo, utilizado nas redes subterrâneas do Rio de Janeiro nas primeiras décadas do século 20'.

Em 1931, eram 41 câmaras transformadoras com capacidade total de 12.300 kVA. Mas a evolução não parou por aí. No início pode ter sido um pouco de estética, outro tanto de invencionismo, mas o fato é que, no Rio de Janeiro, em 25 de julho de 1938, os cabos aéreos de baixa e alta tensão estavam atrapalhando o plano de embelezamento da Capital da República. Assim sendo, o Governo Federal dispôs de um plano para substituir gradativamente a rede aérea. A Light estabeleceu um acordo com a Société Anonyme Du Gaz do Rio de Janeiro e determinou a colocação subterrânea dos cabos de iluminação pública e dos de alta tensão. Claro que os bairros mais nobres foram o ponto de partida da mudança. A Zona Sul carioca, os bairros oceânicos, foram os primeiros e levariam cinco anos para a conclusão da reforma no Leme, Copacabana e Ipanema. (MARTINS, 2012)
\end{abstract}

A rede subterrânea da Light é a maior do país. Com 5,7 mil km de extensão, atende a 500 mil consumidores das regiões do Centro, Zona Sul, Barra da Tijuca e parte da Zona Norte (LIGHT, 2012).

Contudo, a cidade do Rio de Janeiro continua sendo notícia, inclusive no noticiário internacional, quando o assunto é acidentes envolvendo redes subterrâneas de distribuição de eletricidade e de gás natural.

O caso mais grave ocorreu em Copacabana, em junho de 2010, com o casal de turistas americanos Sara Lowry (que teve cerca de $80 \%$ do corpo queimado) e David McLaugheim (que ficou com ferimentos em aproximadamente 35\% do corpo).

Os problemas revelam as precariedades da infraestrutura envelhecida e do descontrole público do subsolo carioca. Em 2011 foi assinado convênio entre o Município do Rio de Janeiro e as concessionárias Companhia Estadual de Águas e Esgotos (CEDAE), Companhia Estadual de Gás (CEG), companhia telefônica OI e empresa carioca de distribuição de energia elétrica Light para elaboração do inédito mapeamento digital do subsolo da cidade. O projeto de mapeamento tem como objetivo auxiliar as empresas no planejamento de operações no subsolo da cidade, a fim de reduzir risco de acidentes e incidentes em ativos de outras concessionárias na mesma área.

A produção legislativa atualmente em vigor do Município do Rio de Janeiro que trata do uso e ocupação do subsolo carioca está dispersa em várias leis e decretos municipais. Primeiro destaque é para a Lei n ${ }^{\circ} 2.776$, de 19 de abril de 1999, que já autorizava a criação de mecanismos para possibilitar a cobrança pecuniária pela utilização do subsolo. 
O monitoramento do armazenamento subterrâneo de líquidos combustíveis de uso automotivo está previsto na Lei no 2.833, de 30 de junho de 1999.

A Lei $n^{\circ} 4.017$, de 26 de abril de 2005, dispõe sobre o uso de vias públicas, espaço aéreo e do subsolo para implantação e passagem de equipamentos urbanos destinados à prestação de serviços de infraestrutura por entidades de direito público e privado. A referida lei introduziu a necessidade de prévia aprovação dos projetos (art. $2^{\circ}$ ), contribuição pecuniária mensal (art. $8^{\circ}$ ) e estabeleceu prazo para as empresas apresentarem mapa detalhado dos equipamentos que estiverem instalados (art. 13).

O Decreto $n^{\circ}$ 26.912, de 21 de agosto de 2006, apesar de não especificar as obras subterrâneas, regulamentou o licenciamento ambiental, a avaliação de impactos ambientais e o cadastro ambiental municipal, vindo a constituir um marco legal na proteção ambiental do Município do Rio de Janeiro.

A regulamentação da permissão de uso de logradouros públicos e das obras de arte, inclusive as especiais, sob domínio municipal, e sua remuneração foi possível com a publicação do Decreto $n^{\circ} 28.002$, de 30 de maio de 2007.

O "ponto alto" da legislação do Município do Rio de Janeiro é a aprovação e publicação do Plano Diretor de Desenvolvimento Urbano Sustentável, por meio da Lei Complementar $\mathrm{n}^{\mathrm{o}} 111$, de $1^{\circ}$ de fevereiro de 2011. Ressalta-se o art. 44, que remete à Lei de Uso e Ocupação do Solo a responsabilidade de ordenamento do subsolo; o art. 63 estabelece que o controle, monitoramento e fiscalização ambiental da poluição do subsolo ficam a cargo da legislação ambiental municipal; o art. 118 dispõe a responsabilidade do órgão central de planejamento e gestão ambiental para realizar o controle das atividades potencialmente poluidoras, inclusive do subsolo; o art. 219 estabelece que são objetivos da Política de Saneamento e Serviços Públicos ordenar a ocupação, funcionamento e implantação de sistemas operacionais em galerias técnicas e dutos no subsolo; o art. 326, por fim, impõe o prazo de cinco anos, a partir da aprovação desta Lei Complementar, para as concessionárias de serviços públicos de eletricidade, telefonia e televisão a cabo, implantarem sua fiação no subsolo urbano, eliminando toda a fiação aérea na Cidade, sob pena de multa diária.

Finalmente, em legislação recente, o Rio de Janeiro estabeleceu, por meio do Decreto $n^{\circ} 37.035$ de 15 de abril de 2013, a regulamentação acerca da implantação de infraestrutura municipal de dutovias de fibra óticas no território do Município. Conforme determina o texto regulamentar, a partir da sua publicação as concessionárias de serviços públicos de eletricidade, telefonia e televisão a cabo ficam obrigadas, às suas custas, a implantar sua 
fiação no subsolo urbano durante as obras de abertura de vias e logradouros públicos, bem como de construção de corredores viários na cidade.

\subsection{Belo Horizonte}

O município de Belo Horizonte possui uma área total de aproximadamente $335 \mathrm{~km}^{2}$, sendo que $83 \%$ do território encontra-se recoberto pela mancha urbana.

A urbanização foi iniciada a partir de um planejamento elaborado no final do século XIX que previa a ocupação da atual região central da capital. A partir da década de 1930, porém, inicia-se um processo intenso de ocupação das periferias imediatas ao plano inicial.

A cidade mineira possui uma grande rede de infraestrutura instalada no subsolo, como redes de distribuição de energia elétrica, água e esgoto, TV a cabo e telefonia, gás natural, dentre outros.

A Praça Sete, no Centro da cidade, foi a primeira região a ter sua fiação elétrica aterrada, em 1971. De 1971 para cá, a Cemig aterrou apenas 366 quilômetros da sua rede elétrica na capital. Na década de 1980, o sistema foi expandido para outras regiões do Centro. Na mesma época, cidades históricas de Minas começaram a substituir a rede aérea pela subterrânea, como Ouro Preto, Diamantina, Mariana, Tiradentes e Serro, mas são pequenos trechos e o trabalho não foi adiante. Na década de 1980, Juiz de Fora, Uberlândia, Uberaba, Itajubá e Montes Claros tiveram parte da fiação aterrada. Na década de 1990, foram construídas redes subterrâneas em Varginha, Nova Lima e Santa Luzia (FERREIRA, 2013).

As normas que regem o uso e ocupação do subsolo no Município de Belo Horizonte estão previstas em várias leis e decretos.

A Lei $n^{\circ} 7.165$, de 27 de agosto de 1996, que instituiu o Plano Diretor do Município de Belo Horizonte, estabeleceu no seu art. 34 as diretrizes relativas ao subsolo para possibilitar o desenvolvimento urbano visando melhorar as condições de vida no Município.

Consoante ao Plano Diretor do Município, a Lei no 7.166, de 27 de agosto de 1996, estabeleceu as normas e condições para parcelamento, ocupação e uso do solo urbano no município e, por meio do art. $1^{\circ}$ do Decreto $n^{\circ} 10.317$, de 28 de julho de 2000, dispôs sobre a cobrança de preço público pelo uso das vias públicas e obras de arte do Município para as finalidades que especifica.

A Lei $n^{\circ} 8.595$, de 18 de junho de 2003, que dispõe sobre o uso do espaço público municipal pelo agente detentor de infraestrutura, estabeleceu no seu art. $1^{\circ}$ a permissão onerosa para instalação de equipamentos subterrâneos no subsolo do Município de Belo 
Horizonte, bem como previu, no art. $4^{\circ}$, a necessidade de construção de galeria técnica no subsolo para implantação, instalação e passagem de equipamento e, no art. $5^{\circ}$, o uso compartilhado de galeria técnica no subsolo.

A Lei $\mathrm{n}^{\mathrm{o}}$ 8.616, de 14 de julho de 2003, regulamentada pelo Decreto $\mathrm{n}^{\mathrm{o}} 14.060$, de 06 de agosto de 2010, que contém o Código de Posturas do Município de Belo Horizonte, instituiu no art. 43-A a obrigatoriedade de licenciamento ambiental prévio para instalação de mobiliário urbano subterrâneo, assim definido nos termos do art. 59 dessa lei.

Para atender à demanda da população por vagas de estacionamento, o Município de Belo Horizonte, lançou projeto de Concessão Comum para construção, operação e manutenção de estacionamentos públicos subterrâneos na cidade. A ideia é que o parceiro privado seja responsável pela construção, manutenção e operação dos estacionamentos subterrâneos do município (PBH, 2012).

A aludida Concessão Comum tornou-se viável a partir da publicação da Lei $n^{\circ}$ 10.379, de 9 de janeiro de 2012, regulamentada pelo Decreto ${ }^{\circ} 14.938$, de 26 de junho de 2012, que autoriza o Município a delegar a construção, a implantação, a gestão, a manutenção e a operação de serviços públicos de estacionamento e infraestruturas correspondentes.

\subsection{Porto Alegre}

A experiência gaúcha do Município de Porto Alegre tem sido considerada como exemplo a ser seguido para as demais cidades brasileiras quando o assunto é a ocupação do espaço subterrâneo (CAMPOS et al, 2006), pois possui uma legislação específica para o licenciamento ambiental de redes de infraestrutura urbana e, principalmente, tem conseguido resultados efetivos na sua aplicação.

Um dos aspectos mais relevantes na legislação da cidade de Porto Alegre é a existência do Plano de Desenvolvimento Urbano Ambiental (PDDUA), instituído pela Lei Complementar $\mathrm{n}^{\circ} 434$, de $1^{\circ}$ de dezembro de 1999 , que vai além do tradicional Plano Diretor existente em outros municípios.

O atual PDDUA, instituído pela Lei Complementar $n^{\circ} 434$, de $1^{\circ}$ de dezembro de 1999 e atualizado pela Lei Complementar nº 646, de 22 de julho de 2010, é, na verdade, “o encontro de duas consagradas bandeiras: a Porto Alegre do Planejamento Urbano e a Porto Alegre da participação dos cidadãos, do Orçamento Participativo, dos Conselhos Municipais e da Governança Solidária Local”' (PREFEITURA MUNICIPAL DE PORTO ALEGRE, 2010, p. $3)$. 
Destaca-se no texto legal do PDDUA a presença de diretrizes gerais, tais como: conceituação de equipamento urbano (art. 72); necessidade de as normas de licenciamento observarem os limites específicos do subsolo (art. 96); a possibilidade de construção de estacionamentos subterrâneos mediante concessão para exploração econômica (art. 133, caput); a menção a áreas especiais para implantação de bacias de contenção de águas pluviais art. 133, parágrafo único); e o estabelecimento de prazo para identificar áreas contaminadas no subsolo (art. 154, XXV).

A cobrança pela utilização e pela passagem dos dutos no bem público está prevista na Lei $n^{\circ} 8.712$, de 19 de janeiro de 2001. Destaca-se no texto legal a caracterização da utilização do subsolo (art. $2^{\circ}$ ); a determinação do regime jurídico de direito público para utilização do subterrâneo $\left(\operatorname{art.} 3^{\circ}\right)$; necessidade de firmar concessão, permissão ou autorização de uso (art. $4^{\circ}$ ); expedição de normas técnicas pelo Município (art. $7^{\circ}$ ); e prazo para regularização das instalações existentes (art. $\left.8^{\circ}\right)$.

A regulamentação dessa Lei ocorre por meio da publicação do Decreto ${ }^{\circ}{ }^{13.384}$, de 10 de setembro de 2001, que introduz o incentivo do Município para formação de consórcios entre empresas que necessitam utilizar o subsolo, de forma a evitar a constante abertura de valas na cidade.

Um dos mais importantes pontos da legislação porto-alegrense é a possibilidade de remuneração da concessão pelo uso do espaço subterrâneo com a conversão em dação em pagamento. Isto significa que, ao invés de efetuar o pagamento, o empreendedor poderá construir um duto e entregá-lo ao Município, bem como poderá doar equipamentos, como caixas de passagem ou emenda, cabos de fibra e outros.

Os dutos dados em pagamento ficam disponíveis para, futuramente, serem ofertados a empresas que ganharem a concessão da Agência Nacional de Telecomunicações (Anatel) para se instalarem no Município, mediante o pagamento de mensalidade.

Por fim, a legislação de Porto Alegre previu, também, por meio do Decreto $\mathrm{n}^{\circ}$ 13.442, de 22 de outubro de 2001, a aprovação de passarelas subterrâneas e a respectiva cobrança pela utilização desse espaço de propriedade pública municipal.

\section{POSSIBILIDADES E LIMITAÇÕES NA GESTÃO DO SUBSOLO URBANO}

As sociedades contemporâneas têm passado por profundas transformações no que tange à concentração de pessoas nas grandes cidades. A dinâmica ocupação territorial das 
cidades é passível de conflitos, dada a escassez de recursos e, principalmente, de espaço para atender à demanda das pessoas por moradia, trabalho e serviços urbanos.

A experiência internacional tem demonstrado que o uso e a ocupação do subsolo urbano tornaram-se opções cada vez mais frequente em várias cidades do mundo. Atividades que tradicionalmente desenvolviam-se na superfície estão se transferindo para o espaço subterrâneo, com destaque para o transporte público (metrô), estacionamentos públicos, centros comerciais, casas de show e teatros, redes de serviços públicos, centros de arte e cultura, dentre outras.

A opção por locação de atividades no subterrâneo pode contribuir para a melhoria do meio ambiente urbano. Destinar certas atividades que não seriam possíveis de ser desenvolvidas na superfície, seja por restrições legais, da comunidade ou mesmo a ausência de áreas disponíveis, contribui para aumentar o nível de qualidade de vida das pessoas. A superfície da terra pode ser reservada para as coisas que queremos ver e ter ao nosso redor, como casas, escolas, jardins, parques, enquanto todas as outras instalações que são necessárias para fazer funcionar a cidade, podem ser instaladas no subsolo.

Contudo a utilização do espaço subterrâneo impõe a necessidade de planejamento urbano que leve em consideração as necessidades atuais e futuras da população. Os benefícios e limitações do uso do subsolo urbano só podem ser verificados caso o planejamento se transforme em peça chave do pensamento dos planejadores e em campo específico de pesquisa. Este, no entanto, parece ser um obstáculo a ser transposto.

Para Daniela Diniz Rodrigues, há entre os planejadores, certa resistência em incluir o espaço subterrâneo na agenda do planejamento urbano.

Os planejadores urbanos não se interessam pelo espaço subterrâneo, e uma das razões é, provavelmente, que a maioria deles ainda pensa no aproveitamento do subsolo como um desafio técnico para a engenharia, e não estão preparados para raciocinar de forma diferente, já que não existe curso relacionado ao assunto no Brasil. (RODRIGUES, 2009, p. 173-174)

Outra questão diz respeito ao conteúdo dos Planos Diretores Municipais, principal ferramenta de planejamento urbano das cidades. Para Priscila Ferreira Blanc, os Planos municipais:

Materializam em documento um processo de planejamento que define objetivos estabelecidos conforme a realidade local e a manifestação da população, bem como os meios para atingi-los, controlar sua aplicação e avaliar seus resultados. (BLANC, 2010, p.112) 
No entanto, conforme Daniela Diniz Rodrigues, a abordagem tridimensional de conceber o urbanismo, em regra, é muito limitada, não dispondo o legislador sobre diretrizes claras sobre ocupação do subsolo, nem tampouco articulação entre o desenvolvimento da superfície e as potencialidades do subterrâneo.

\begin{abstract}
O urbanismo subterrâneo, tridimensional, é opção para encurtar as distancias dos deslocamentos obrigatórios; não é mais caro do que o urbanismo bidimensional, não é o lugar só para os mortos e para arquivo morto (depósito de coisas fora de uso); não é um lugar que expõe os seres humanos a riscos não calculados; não é mais insalubre do que a superfície; não é opção apenas para locais de clima severo; não é recurso que admita falta de planejamento; não é lugar que se possa intervir, errar e reverter o erro; não é lugar que aceite excessos do gosto dispendioso do indivíduo; fornece uma condição mais justa para a distribuição dos recursos sociais existentes em uma cidade. (RODRIGUES, 2009, p. 175)
\end{abstract}

No Brasil, a realidade da maioria dos centros urbanos é caracterizada pela baixa qualidade de vida e pela insustentabilidade ambiental das cidades. A falta de investimentos, a inexistência de articulação dos órgãos do Poder Público responsáveis pela condução da Política Urbana, potencializam os efeitos do crescimento exagerado das cidades. Em consequência, verificam-se ocupações irregulares do tecido urbano, inadequação ou inexistência de saneamento básico e a presença de sistema de transporte público caótico, tudo isso provocando enorme pressão sobre o meio ambiente.

No que se refere ao uso do subterrâneo das cidades brasileiras, a regra é a falta de conhecimento e controle sobre os equipamentos de infraestrutura que se encontram instalados, e, o mais grave, a inércia em relação ao planejamento para ocupação futura.

A pesquisa legislativa identificou no nível federal, bem como nas legislações dos Municípios de São Paulo, Rio de Janeiro, Belo Horizonte e Porto Alegre, que existe um conjunto de normas, quase todas semelhantes, tratando de temas como: permissão municipal para uso e ocupação do subsolo; licenciamento ambiental e urbanístico como ferramenta de controle e gestão; compartilhamento de infraestruturas subterrâneas; pagamento pelo uso do espaço do subsolo urbano; dentre outros.

Para Edésio Fernandes (2012), o Direito brasileiro não ignora a necessidade de promoção da reforma urbana e, de fato, existe uma miríade de leis sobre matérias de desenvolvimento territorial, planejamento e gestão urbana.

Ademais, a simples existência de texto legal não garante a eficácia do processo, muito menos o cumprimento das normas de controle e fiscalização por parte dos Administradores Municipais. 
A previsão legal de cobrança pelo uso do espaço subterrâneo e a necessidade de cadastro e mapeamento dos usos, por exemplo, são temas presentes há tempos em algumas legislações municipais. Entretanto, a inércia dos sucessivos administradores tem postergado sua exigência. Nessa toada, as cidades, e principalmente os cidadãos, até hoje, desconhecem o que está instalado sob seus pés.

Tomando-se como parâmetro o Plano Diretor Subterrâneo desenvolvido pela cidade de Helsinki, apesar do avanço legislativo apresentado, as cidades brasileiras estão muito longe de conceber um planejamento do subsolo urbano.

Com o objetivo de disciplinar a ocupação subterrânea, há a necessidade de uma legislação específica e organizada, que limite e forneça as diretrizes básicas para obras enterradas e ainda estabeleça as responsabilidades e atribuições por eventuais acidentes ou impactos decorrentes destas intervenções. O não cumprimento desse requisito resulta na impossibilidade de uma gestão planejada, integrada e global sobre a ocupação do solo e subsolo (CAMPOS et al, 2006).

À exceção de Porto Alegre, não foi identificada ação efetiva que represente a existência de planejamento integrado visando a ocupação do subsolo nas cidades.

Os Planos Diretores das cidades brasileiras pesquisadas seguem quase sempre a mesma linha quando se refere à ocupação do espaço público do subsolo, qual seja, faltam regras claras e abordagem tridimensional. As três fronteiras do espaço urbano - superfície, abaixo e acima dele, são reconhecidas e exploradas de forma independente umas das outras. Por consequência, inexiste o planejamento de ocupação futura do subsolo.

Dessa forma, torna-se urgente que o Poder Público estabeleça um Plano Diretor Subterrâneo, a exemplo do "Underground Master Plan of Helsinki" já implantado na capital da Finlândia, estabelecendo diretrizes de ocupação, semelhantes ao zoneamento urbano existente para a superfície, para possibilitar o ordenamento da ocupação do espaço subterrâneo urbano.

O Plano Diretor Subterrâneo deve ser precedido de seu mapeamento, abordando os aspectos geológicos e a rede de infraestrutura existente. Com esse mapeamento será possível definir, conforme a vocação e os limites naturais de cada área, aquelas a serem destinadas para implantação dos diferentes tipos de obras e equipamentos subterrâneos, bem como aquelas destinadas para usos público e particular, mediante outorga do Poder Público.

A definição dessas áreas e das diretrizes para utilização do subsolo possibilita a segurança jurídica necessária ao investimento privado, incentivando a modernização de infraestrutura nos centros urbanos e o desenvolvimento social e econômico das cidades. De 
fato, a ausência de parâmetros e definição de marco jurídico tende a desencorajar (ou pelo menos tornar mais difícil e, portanto, mais caro) o uso adequado da tecnologia no subsolo.

Da mesma forma, na falta de articulação e planejamento do Poder Público, prevalecem os interesses privados, em detrimento do crescimento organizado e do desenvolvimento sustentável urbano.

Verifica-se, portanto, inúmeras possibilidades para o melhor aproveitamento do subsolo, com vistas à melhoria da qualidade do espaço da superfície e o do bem-estar da população. Entretanto, limitações culturais e tecnológicas, bem como a ausência de legislação específica, ainda no século XXI, são os grandes desafios a serem enfrentados.

\section{CONSIDERAÇÕES FINAIS}

O uso mais intensivo do subterrâneo urbano exige que o controle por parte do Poder Público responda aos novos anseios sociais na dimensão da sustentabilidade ainda de forma preventiva, posto que a atividade subterrânea em larga escala ainda está em gestação no Brasil, como em outros Países em todo mundo.

Ao longo deste artigo foram identificados os institutos jurídicos presentes na legislação brasileira para tutela do espaço subterrâneo e confirmada a competência municipal para regular a legislação urbanística, poderes atribuídos pela Constituição de 1988, regulamentada pelo Estatuto da Cidade. Portanto, não há dúvida sobre a autonomia do Município para gestão do subsolo urbano, tendo em vista, ainda, a responsabilidade do Poder Público municipal pela proteção ambiental e melhoria da qualidade de vida nas cidades.

$\mathrm{Na}$ sequência, foram caracterizados os tipos de intervenções no subsolo urbano, frente às exigências de novos padrões de produção para atender o consumo e estudados aspectos legais da experiência internacional e das cidades de São Paulo, Rio de Janeiro, Belo Horizonte e Porto Alegre de intervenção no subsolo urbano.

A pesquisa legislativa identificou a existência de normas dispersas que regulam o uso e ocupação do subsolo em várias legislações dos Municípios pesquisados. No entanto, foi realçado que a existência por si só de texto legal não garante a eficácia da gestão do subsolo.

Há necessidade de uma legislação específica e organizada, que limite e forneça as diretrizes básicas para obras enterradas e ainda estabeleça as responsabilidades e atribuições por eventuais acidentes ou impactos decorrentes de tais intervenções, de forma a propiciar 
segurança jurídica aos candidatos a ocupar esse espaço público e possibilitar o desenvolvimento das futuras intervenções.

Dessa forma, propõe-se que as cidades passem a elaborar um "Plano Diretor Subterrâneo", tendo como tripé de sustentação política de gestão: a regulação, a proteção e a apropriação do espaço subterrâneo urbano. Acredita-se que esse instrumento jurídico, a exemplo do Plano Diretor Subterrâneo de Helsinki, poderá trazer diretrizes de ocupação, semelhantes ao zoneamento urbano existente para a superfície, possibilitando o efetivo ordenamento da ocupação do espaço subsolo urbano.

Mas não pode ser uma transposição mecânica dos atributos jurídicos do solo para o subsolo, pois o objetivo final é o de explorar esse potencial ainda em desenvolvimento, de forma a maximizar os benefícios para o meio ambiente, a sociedade e a economia.

O presente trabalho comprovou a hipótese de que o uso mais intensivo do espaço subterrâneo urbano exige um marco jurídico regulatório que responda aos anseios de desenvolvimento social e econômico das cidades brasileiras, inibindo a exploração predatória e sem controle, o que coloca em risco a integridade física e a qualidade de vida do cidadão, posto que a atividade subterrânea em larga escala ainda está em gestação no Brasil.

Desse modo, sua utilização dentro dos novos padrões de produção e consumo pode ajudar as cidades brasileiras a alcançar metas de desenvolvimento, mediante planejamento de curto, médio e longo prazo, ou seja, não apenas para responder às demandas atuais, mas se preparando também para os desafios vindouros.

\section{REFERÊNCIAS BIBLIOGRÁFICAS}

ARAÚJO, Eloisa Carvalho. Urbanismo subterrâneo: contradições e novas diretrizes. Disponível em: <http://direitoeurbanismo.wordpress.com/2011/09/29/urbanismo-subterraneocontradicoes-e-novas-diretrizes/>. Acesso em: 11 de ago. 2015.

ASSOCIAÇÃO BRASILEIRA DE MECÂNICA DOS SOLOS E ENGENHARIA GEOTÉCNICA - ABMS. O Metrô e o subsolo de São Paulo. Editorial. Julho/2011. Disponível em: <https://www.abms.com.br/home/temas/tuneis/indice/539-o-metro-e-osubsolo-de-sao-paulo>. Acesso em: 04 jul. 2013.

BLANC, Priscila Ferreira. Plano Diretor Urbano \& função social da propriedade. Curitiba: Juruá, 2010.

BOBYLEV, Nikolai. Mainstreaming sustainable development into a city's Master plan: a case of Urban Underground Space use. Land Use Policy, n. 26, p. 1128-1137, 2009. 
Disponível em: <http://www.sciencedirect.com/science/article/pii/S026483770900026X>. Acesso em: 01 jul.2014.

CAMPOS, Gislene Coelho de. O "invisível” espaço subterrâneo urbano. São Paulo em Perspectiva, v. 20, $\mathrm{n}^{\mathrm{o}}$ 2, p. 147-157, abr./jun. 2006. Disponível em: <http://www.seade.gov.br/produtos/spp/v20n02/v20n02_11.pdf>. Acesso em: 25 jun. 2015.

CENSO DEMOGRÁFICO 2010. Características da população e dos domicílios: resultados do universo. Rio de Janeiro: IBGE, 2011. Acompanha 1 CD-ROM. Disponível em: . Acesso em: 20 de mar. 2015.

DESURBS - Designing Safer Urban Spaces. Disponível em: <http://www.desurbs.net/Japan\%20deep\%20underground.html>. Acesso em: 10 mai. 2014

DINIZ, Maria Helena. Lei de Introdução ao Código Civil Brasileiro Interpretada. $8^{a}$ edição. São Paulo: Saraiva, 2001.

FERNANDES, Edésio. A construção do direito urbanístico brasileiro: 10 anos de Estatuto da Cidade, avanços e limites. In: RIOS, Mariza; CARVALHO, Newton Teixeira (orgs.). Direito à Cidade - moradia e equilíbrio ambiental. Belo Horizonte: Del Rey, 2012. p. 7-17.

FRANCISCO, Caramuru Afonso. Estatuto da cidade comentado. São Paulo: Juarez de Oliveira, 2001.

GLOBAL FOOTPRINT NETWORK. Earth Overshoot Day 2011, 2011a. Disponivel em: <http://www.footprintnetwork.org/press/EODay_Media_Backgrounder_2011.pdf >. Acesso em: 20 de mai.2015.

GUNN, J. at all. Law of the underground. In DOBINSON, Ken; BOVVEN, Rod. Underground Space. The urban environment development and use. The Warren Centre for Advanced Engineering The University of Sydney. June 1997.

Disponível em: <http://thewarrencentre.org.au/wp-content/uploads/2012/10/UndergroundSpace_lrf.pdf $>$. Acesso em: 11 de jun. 2015.

HARADA, Kiyoshi. Utilização de subsolo municipal para abertura de túnel interligando os prédios situados ao longo das vias públicas mediante permissão de uso a título oneroso: viabilidade jurídica. 2010.

Disponível em: <http://jus.com.br/revista/texto/18904/utilizacao-de-subsolo-municipal-paraabertura-de-tunel-interligando-os-predios-situados-ao-longo-das-vias-publicas-mediantepermissao-de-uso-a-titulo-oneroso-viabilidade-juridica $\geq$. Acesso em: 11 de ago. 2015.

ITA - Internacional Tunnelling Association. Policy Statement on Legal and Administrative Issues in Underground Space Use.

Disponível em: <http://www.ita-aites.org/fr/publications/wg-publications/content/9/workinggroup-4-subsurface-planning $\geq$. Acesso em: 11 de ago. 2015.

ITACUS, 2010. White Paper. Planning the Use of Underground Space. Disponível em: <http://www.itacus.ita-aites.org>. Acesso em: 11 de ago. 2015. 
JUSTIÇA FEDERAL. Jornadas de direito civil I, III, IV e V: enunciados aprovados. Brasília: Conselho da Justiça Federal, Centro de Estudos Judiciários. 2012. 135 p.

LIGHT SERVIÇOS DE ELETRICIDADE S.A. Light moderniza sua rede subterrânea e ganha prêmio internacional. Disponível em: <http://conexaolight.com.br/tag/redesubterranea >. Acesso em: 12 de ago. 2015.

MUKAI, Toshio. Temas atuais de direito urbanístico e ambiental. Belo Horizonte: Fórum, 2007.

ORGANIZAÇÃO DAS NACÕES UNIDAS - ONU. Declaração do Rio sobre meio ambiente e desenvolvimento. Disponível em:

<http://www.onu.org.br/rio20/img/2012/01/rio92.pdf> Acesso em: 11 de ago. 2015.

PREFEITURA DE BELO HORIZONTE - PBH. Projeto de concessão comum de estacionamentos subterrâneos. 2012. Disponível em: $<$ http://portalpbh.pbh.gov.br/pbh/ecp/comunidade.do?evento=portlet\&pIdPlc=ecpTaxonomia MenuPortal\&app=concessaoestacionamentos\&tax $=26641 \&$ lang $=$ pt_BR\&pg=9781\&taxp=0\& >. Acesso em: 14 jul. 2015.

PREFEITURA DE SÃO PAULO. CONVIAS. 2014. Histórico de CONVIAS. Disponível em: <http://www.prefeitura.sp.gov.br/cidade/secretarias/infraestrutura/convias/organizacao/his torico/>. Acesso em: 14 jul. 2015.

PREFEITURA MUNICIPAL DE PORTO ALEGRE. Secretaria do Planejamento Municipal Plano diretor de desenvolvimento urbano ambiental. 2011. Disponível em:< http://lproweb.procempa.com.br/pmpa/prefpoa/spm/usu_doc/planodiretortexto.pdf $>$. Acesso em: 12 ago. 2015.

RODRIGUES, Daniela Diniz. Urbanismo subterrâneo. Argumentos éticos para o uso e a ocupação do solo. 2009. 197 f. Tese (Doutorado em Arquitetura e Urbanismo) - Faculdade de Arquitetura e Urbanismo, Universidade de Brasília, 2009.

ROLNIK, Raquel.. Plano Diretor de São Paulo: avaliação da União dos Movimentos de Moradia. Mai/2013. Disponível em: <http://raquelrolnik.wordpress.com/2013/05/29/planodiretor-de-sao-paulo-avaliacao-da-uniao-dos-movimentos-de-moradia/>. Acesso em: 11 de ago. 2015.

SILVA, R.T.; MACHADO, L. Serviços urbanos em rede e controle público do subsolo Novos desafios à gestão urbana. São Paulo em Perspectiva, São Paulo, Fundação Seade, v. 15 , n. 1, 2001.

TORRES, Vital F. N.; GAMA, Carlos Dinis da. Engenharia ambiental subterrânea e aplicações. Rio de Janeiro: CETEM/CYTED, 2005. Disponível em: <http://www.cetem.gov.br/publicacao/livros/EngenhariaAmbientalSubterranea.pdf $>$. Acesso em: 11 de ago. 2015.

VAHAAHO, I. Underground Master Plan of Helsinki. A city growing inside bedrock. 2012. 
ND+MASTER+PLAN+OF+HELSINKI.pdf?MOD=AJPERES\&CACHEID=a58483004e 108 33e8265a3f50c17d44f>. Acesso em: 11 de ago. 2015.

VENOSA, Silvio de Salvo. Direito Civil: Direitos Reais. 2a ed. São Paulo: Atlas, 2002.

XINHUA NEWS AGENCY. Pequim explora o espaço subterrâneo para aliviar o congestionamento do chão. Disponível em:

<http://www.china.org.cn/english/China/188683.htm>. Acesso em: 03 jul. 2015. 